\title{
REDUÇÃO DO CONSUMO DE ÁGUA EM UMA TORRE DE RESFRIAMENTO PELA UTILIZAÇÃO DE UM NOVO BIOCIDA*
}

\author{
Anderson José Beber ${ }^{1}$ \\ Renato André Nunes Pereira ${ }^{2}$ \\ Roberto Strieder ${ }^{3}$
}

\begin{abstract}
Resumo
O trabalho apresenta os resultados da aplicação de um novo oxidante moderado em uma grande torre de resfriamento utilizada em sistema de geração de energia de uma grande usina no sul do Brasil. Esta torre de refrigeração utiliza água de efluente tratado (tratamento terciário Esgoto doméstico) como fonte de reposição. Com aplicação desta nova tecnologia, houve uma melhoria tanto no controle microbiológico como na taxa de corrosão. Além disso, a planta foi capaz de aumentar o ciclo de concentração, resultando em economia de água, produtos químicos e menor geração de efluente, possibilitando economia superior a $\mathrm{R} \$ 500.000 / A n o$, aplicando conceito de reuso.
\end{abstract}

Palavras-chave: Biocida; Oxidante; Reuso; Torre de Resfriamento

\section{REDUCTION ON WATER CONSUMPTION ON A COOLING TOWER WITH THE APPLICATION OF A NOVEL BIOCIDE}

\begin{abstract}
The objective of this paper is to present the results of an application of a new mild oxidizer in a large cooling tower, located at a major power plant in southern Brazil. This cooling tower uses clarified sewage (tertiary treated domestic wastewater) as its makeup water. After the application of this technology, there was a significant improvement on microbiological growth and corrosion rates. Besides, the plant was able to raise concentration cycles, which lead to water and chemicals savings, and less wastewater generation. Total savings surpassed $R \$ 500.000$ per year, applying the important reuse concept.
\end{abstract}

Keywords: Biocide; Reuse; Oxidizing; Cooling Tower

1 B.Sc.Chemical Engineer, Applications Project Manager, Industrial Water Division, Solenis Especialidades Químicas Ltda,São Paulo,SP, Brasil.

2 Industrial Engineer, Sales Manager, Industrial Water Division, Solenis Especialidades Químicas Ltda,São Paulo,SP, Brasi.l

3 Environmental Technologist, Sales Manager, Industrial Water Division, Solenis Especialidades Químicas Ltda,São Paulo,SP, Brasil. 


\section{INTRODUCTION}

Chloramines have been used as mild oxidizer for many years. There are many known applications of this chemistry for a complete substitution of traditional strong oxidizers such as chlorine gas and sodium hypochlorite. A major advantage of chloramines is that they are more selective compared to the strong oxidizers. This feature makes it a very good candidate for industrial cooling water systems in which there is a high oxidant demand.

Bromide Activated Chloramine (BAC), the microbiocide in this case study, was produced by the reaction under controlled conditions between sodium hypochlorite and ammonium bromide, both diluted in water. The result of this reaction is a unique biocide, BAC. BAC is a mild oxidizer that is very effective in controlling a wide range of biofilm producing microorganisms in recirculating cooling water process streams. The reaction is controlled by a specific piece of equipment which is designed to generate and slug dose the required amount of BAC into the cooling water system. This mild oxidizer does not exhibit some of the adverse effects that are often experienced with most commercially available oxidizers. For example, BAC controls microbiological growth at an overall lower system Oxidation Reduction Potential (ORP), resulting in improved corrosion control.

BAC technology has been used to control microbiological growth for many years in the paper machines and paper production. In 2003, the United States Environmental Protection Agency (EPA) approved it as a substitute for chlorine as an oxidizer.

\section{MATERIALS AND METHODS}

BAC is produced from the stoichiometric combination of ammonium bromide salt and sodium hypochlorite, described by Equation 1 below.

$$
\mathrm{NH}_{4} \mathrm{Br}+\mathrm{NaOCl} \rightarrow\left[\mathrm{NH}_{2} \mathrm{Cl}\right] \mathrm{Br}^{-}+\mathrm{Na}^{+}+\mathrm{H}_{2} \mathrm{O} \quad \text { Equation (1) (Kiuru, 2011) }
$$

The reaction product, $\mathrm{BAC}$, is a mild oxidizer which has the property of being a selective biocide. The reaction occurs on site, utilizing the specially designed BAC generating equipment. Figure 1 describes the on-site reaction and consequent dosage to the cooling tower basin.

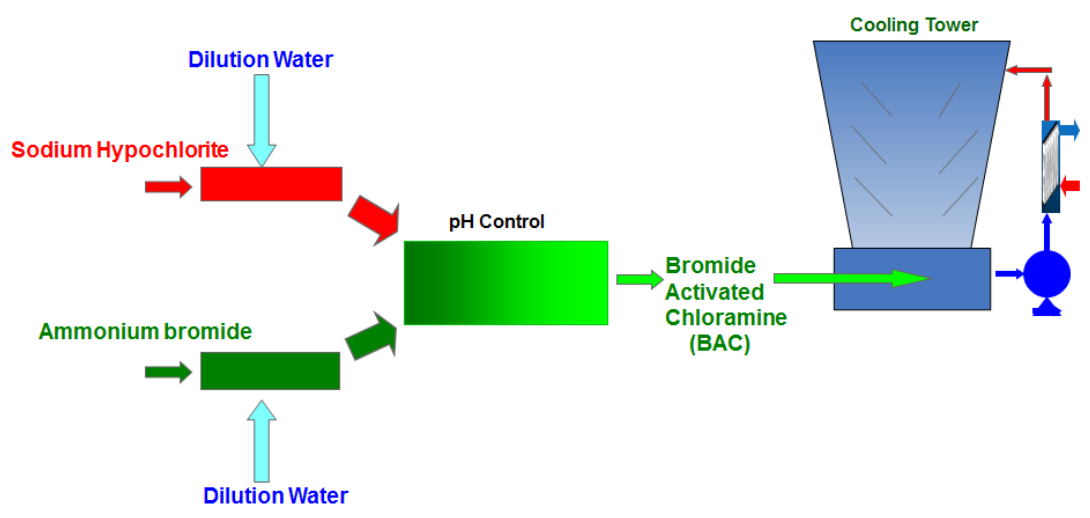

Figure 1: On-site production and dosage of BAC. 
Once the BAC is produced, it is immediately dosed to the cooling tower basin. These slug dosages may vary from 2 up to $5 \mathrm{ppm}$ BAC measured as total chlorine. The amount of BAC required is dependent on the cleanliness of the system, where fouled systems may require higher dosages. Also, since it is a mild oxidizer, as explained later it usually operates within lower ORP range compared to a strong oxidizer.

Biofilm formation - Figure 2 describes the 5 stages process of biofilm formation and migration to the bulk water. Whenever a system is not well controlled - and biofilm is formed - most strong oxidizers (such as chlorine dioxide, sodium hypochlorite and chlorine gas), will not have a high effectiveness on stages 3 and 4 . The biofilm is formed from the production of exopolysaccharides (EPS) by bacteria and provides a natural protection for the bacteria. Once it is formed, this natural EPS layer consume most the strong oxidizer since it is not selective. Thus this strong oxidizer will hardly penetrate the biofilm to effectively attack the microorganisms.

Due to the ability of being selective, BAC does not react with EPS and is able to penetrate the biofilm and attack the microorganisms. In fact, with proper application, BAC is capable of providing on-line clean-up of a bio fouled system. However, it is important to mention that the main objective is to avoid any kind of biofilm formation, by constantly controlling the key operating and key performance indicators.

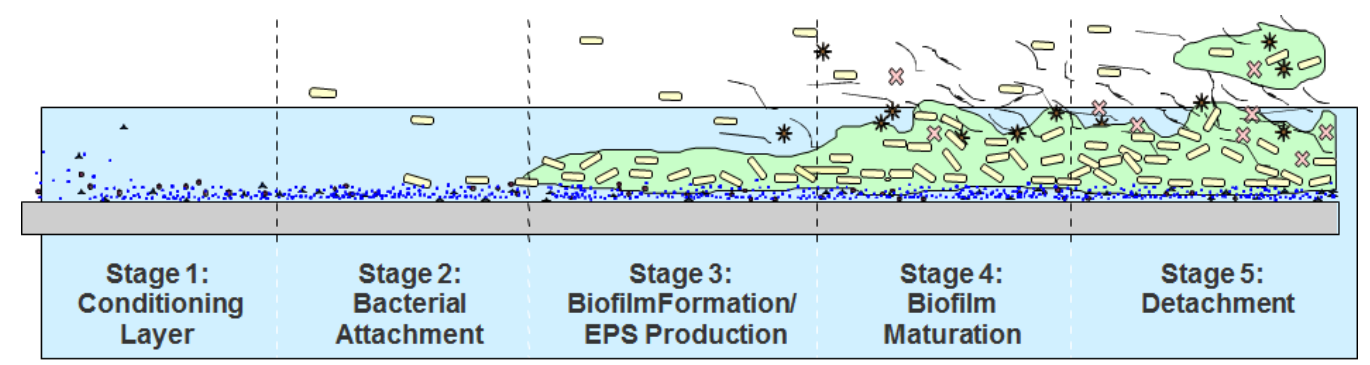

Figure 2: Biofilm evolution and formation in an uncontrolled water system (Graphic by Peg Dirckx and David Davies, 2003, Center for Biofilm Engineering, Montana State University)

As described above, BAC dosage requirement is quite low compared to strong oxidizers in a fouled system. For this reason, the usage of BAC reduces significantly the amount of chlorinated and/or brominated organic materials and chloride residuals. If sulfuric acid is used to control $\mathrm{pH}$, sulfate residual is also reduced.

ORP Control Range - In most microbiological control programs using an oxidizing biocide, achieving a certain minimum oxidation-reduction potential, aka ORP, is essential to providing good microbiological control. Strong oxidizers are usually controlled to generate an ORP range between $400-600 \mathrm{mV}$, depending upon the chemical program. The greater the ORP level, the more effective the biocide is. The corrosivity of a cooling water system is primarily a function of the following variables: temperature, $\mathrm{pH}$, ORP, dissolved solids (especially chloride and sulfate ions), and deposits (i.e., underdeposit corrosion) (Baron, 2012). However, high ORP values may result in higher corrosion rates. 
BAC is a mild oxidizer, generating a maximum ORP level of approximately $375 \mathrm{mV}$. The usual control range is between $200-300 \mathrm{mV}$. The effectiveness and benefits of this lower ORP range will be detailed ahead, with the comparison on the usage of sodium hypochlorite and BAC at the selected cooling tower.

Selectivity - The acting mechanism on how BAC is more selective is most likely due to its capacity to react with specific chemical bonds. Although the exact mechanism is not yet proven, it is believed that BAC is selective to react with:

$\rightarrow$ sulphihydryl bonds (-S-H-) also called thiol bonds in the microorganism; $\rightarrow$ disulphide bonds (-S-S-) between proteins in the microorganism;

This possible selectivity of BAC to break sulfur bonds can be compared to the ability of chloramines reacting with the same bonds (Peskin and Winterbourn, 2006).

The redox reaction destroys and deactivates the various biochemicals inside the cell and stops the production of energy. This lack of energy for the microorganism cell leads either to death or cell release from the biofilm to the bulk flowing water. These cells which were previously entrapped in the biofilm will then react with BAC in the bulk flowing water. Very important, BAC is not consumed by other organic compounds.

This is considered one the great features of BAC technology, especially in a fouled system or in cooling systems that suffer regular contamination. Also it is especially effective in cooling systems where the make-up water may have a high oxidant demand, for example, grey water or recycled water.

\subsection{POWER PLANT COOLING TOWER OPERATION}

A large power plant in the South of Brazil was selected for a case study with BAC as a substitute for sodium hypochlorite, because of several concerns arising from high hypochlorite usage. Table 1 shows the operational data of the cooling tower at this power plant. Total power produced at this site is around $469 \mathrm{MW}$.

\begin{tabular}{|l|c|c|}
\hline System volume & $\mathrm{m}^{3}$ & 3000 \\
\hline Recirculating rate & $\mathrm{m}^{3} / \mathrm{h}$ & 24325 \\
\hline Evaporation & $\mathrm{m}^{3} / \mathrm{h}$ & 430 \\
\hline Total blowdown & $\mathrm{m}^{3} / \mathrm{h}$ & 120 \\
\hline Concentration cycles & - & 4.50 \\
\hline$\Delta \mathrm{T}$ & ${ }^{\circ} \mathrm{C}$ & 10.85 \\
\hline Make up rate & $\mathrm{m}^{3} / \mathrm{h}$ & 550 \\
\hline
\end{tabular}

Table 1 - Operational data of the cooling tower in study.

This power plant is located in an industrial/refinery area, where there is a local water and sewage company that provides grey water (treated and clarified sewage) as the make-up water to the cooling tower. As expected, this source of water has several components that in fact represent oxidant demand: organics and ammonia mostly. Table 2 describes the average condition of the make-up water. 


\begin{tabular}{|l|c|c|}
\hline $\mathrm{pH}$ & - & 6.90 \\
\hline Alkalinity & $\mathrm{ppm} \mathrm{CaCO}_{3}$ & 75 \\
\hline Conductivity & $\mu \mathrm{S} / \mathrm{cm}$ & 410 \\
\hline Chlorides & $\mathrm{ppm} \mathrm{Cl}$ & 42 \\
\hline Sulfates & $\mathrm{ppm} \mathrm{SO}_{4}$ & 38 \\
\hline Total Hardness & $\mathrm{ppm} \mathrm{CaCO}_{3}$ & 55 \\
\hline Calcium Hardness & $\mathrm{ppm} \mathrm{CaCO}_{3}$ & 32 \\
\hline Silica & $\mathrm{ppm} \mathrm{SiO}_{2}$ & 10 \\
\hline Ammonia & $\mathrm{ppm} \mathrm{NH}_{3}$ & 12 \\
\hline Iron & $\mathrm{ppm} \mathrm{Fe}$ & 0.20 \\
\hline
\end{tabular}

Table 2 - Average chemical profile of the make-up water to the cooling tower.

Other important variables such as TOC, COD and suspended solids unfortunately are not controlled by the plant personnel.

Because of the high oxidant demand in the make-up water, the consumption of sodium hypochlorite was quite significant. An average of $40,000 \mathrm{~kg}$ per month was quite common. Because of this high sodium hypochlorite consumption, large quantities of sulfuric acid were also necessary to maintain an adequate $\mathrm{pH}$ level and also for better performance of sodium hypochlorite. Sulfuric acid monthly usage was around 15,000 $\mathrm{kg}$ per month. However, even with this large consumption of sodium hypochlorite, the residual free chlorine was very low. Also typical ORP was around $350-400 \mathrm{mV}$ which is low for good MB control using hypochlorite. This was caused by a major decision taken by the plant a few year back: to limit a maximum of $600 \mathrm{ppm}$ of chlorides + sulfates in the cooling water. The plant established that this is the maximum desirable limit to avoid SCC (stress corrosion cracking). Our company did not agree with this upper limit based on the lack of historical information and failures. However, our company respected this guideline and used this to assess the benefits of BAC over sodium hypochlorite. According to the plant personnel, this limit was established in accordance between themselves and the equipment (surface condenser) provider.

The consequences of this limitation on the chlorides + sulfates residual were frequent biological fouling of the surface condenser despite the large quantities of hypochlorite used. Typical sodium hypochlorite dosages varied in the range $6-20 \mathrm{ppm}$, depending upon the amount of chlorine demand present in the makeup water. This restriction chlorides + sulfates residual resulted in an average of 4.5 cycles of concentration.

The challenges presented by the plant were:

$\rightarrow$ Enhance cleanliness and reduce biofouling in the system, especially in the surface condenser tubes

$\rightarrow$ Reduce sodium hypochlorite and sulfuric consumption

$\rightarrow$ Reduce tower blowdown and consequently water consumption

$\rightarrow$ Reduce $\mathrm{Cl}$ and $\mathrm{SO}_{4}$ residuals in the recirculating water

Table 3 shows the average results for chemical testing in the recirculating water at the cooling tower. Note that even with a high sodium hypochlorite consumption, average free chlorine was not significant. 


\begin{tabular}{|l|c|c|}
\hline $\mathrm{pH}$ & - & $7.50-7.90$ \\
\hline Alkalinity & $\mathrm{ppm} \mathrm{CaCO}_{3}$ & $90-280$ \\
\hline Conductivity & $\mu \mathrm{S} / \mathrm{cm}$ & $1700-2200$ \\
\hline Chlorides & $\mathrm{ppm} \mathrm{Cl}^{\mathrm{C}}$ & $200-350$ \\
\hline Sulfates & $\mathrm{ppm} \mathrm{SO}_{4}$ & $420-520$ \\
\hline ORP & $\mathrm{mV}$ & $350-400$ \\
\hline Total Hardness & $\mathrm{ppm} \mathrm{CaCO}_{3}$ & $300-400$ \\
\hline Calcium Hardness & $\mathrm{ppm} \mathrm{CaCO}_{3}$ & $180-280$ \\
\hline Silica & $\mathrm{ppm} \mathrm{SiO}_{2}$ & $55-75$ \\
\hline Iron & $\mathrm{ppm} \mathrm{Fe}$ & $0.4-0.9$ \\
\hline Free Chlorine & $\mathrm{ppm} \mathrm{Cl}_{2}$ & $0.1-0.2$ \\
\hline
\end{tabular}

Table 3 - Average chemical profile of the recirculating water prior to the BAC dosage.

Other important variables such as TOC, COD and suspended solids unfortunately are not controlled by the plant personnel.

\subsection{BAC PROPOSED DOSAGE}

A complete substitution of sodium hypochlorite (12\% active) by BAC was presented along with elimination/reduction on sulfuric acid dosage for $\mathrm{pH}$ correction. The objectives were:

$\rightarrow$ Eliminate sodium hypochlorite dosage to the tower (sodium hypochlorite only necessary to produce BAC)

$\rightarrow$ Eliminate sulfuric acid consumption

$\rightarrow$ Water savings after concentration cycles change

$\rightarrow$ Better biofilm/sludge control in the system

The dosage was started in April 2015, after the set up and preparation of the plant. The control equipment was adjusted to produce BAC according to Equation 1. Also acid feed was stopped.

This new biological growth control program was designed to provide at least $3 \mathrm{ppm}$ BAC (measured as total chlorine) during the feed cycles. The slug feed frequency was initially set for 3 times each 24 hours. Figure 3 shows the ORP profile with its typical spikes which correspond to the slug feed. Note that on each feed, a higher ORP is reached which is an indication that the system was becoming easier to treat and control. 


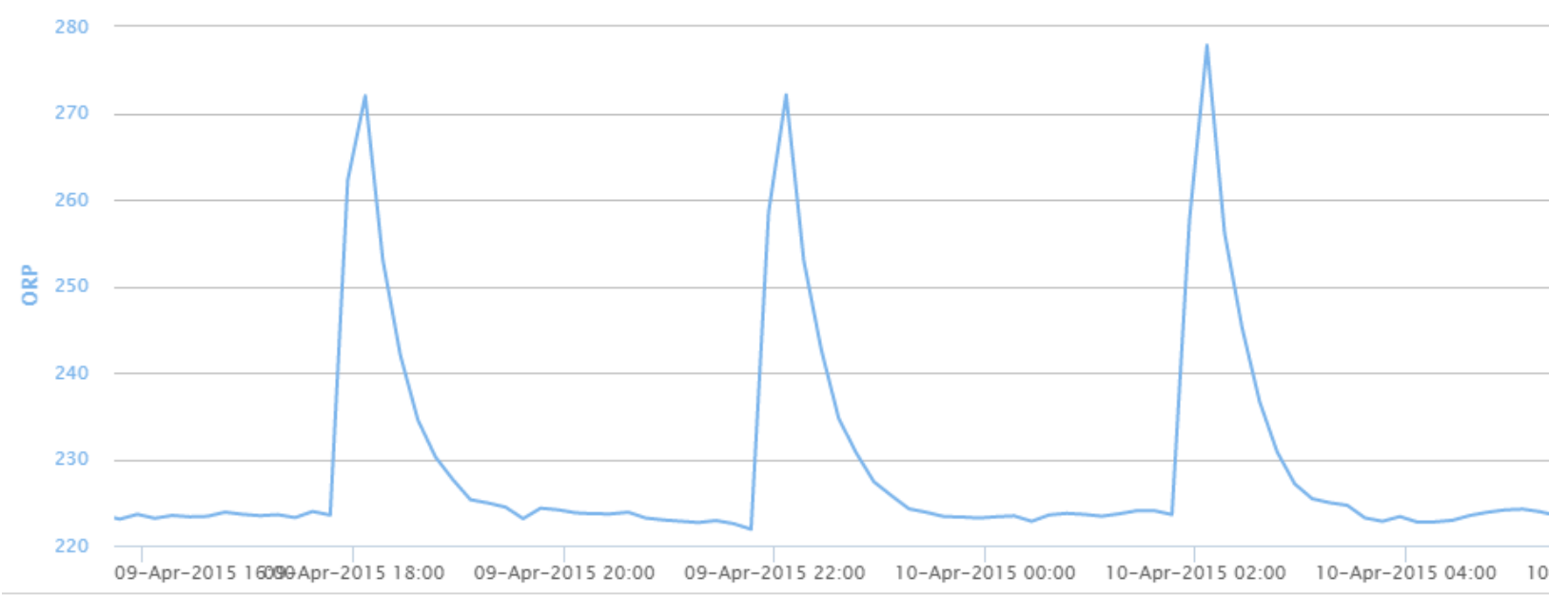

Figure 3 - ORP profile during slug feeds of BAC.

\section{RESULTS AND DISCUSSION}

As described previously, on the immediate start of BAC usage, sulfuric acid dosage was interrupted. Figure 4 shows the $\mathrm{pH}$ profile before and after the BAC dosage start.

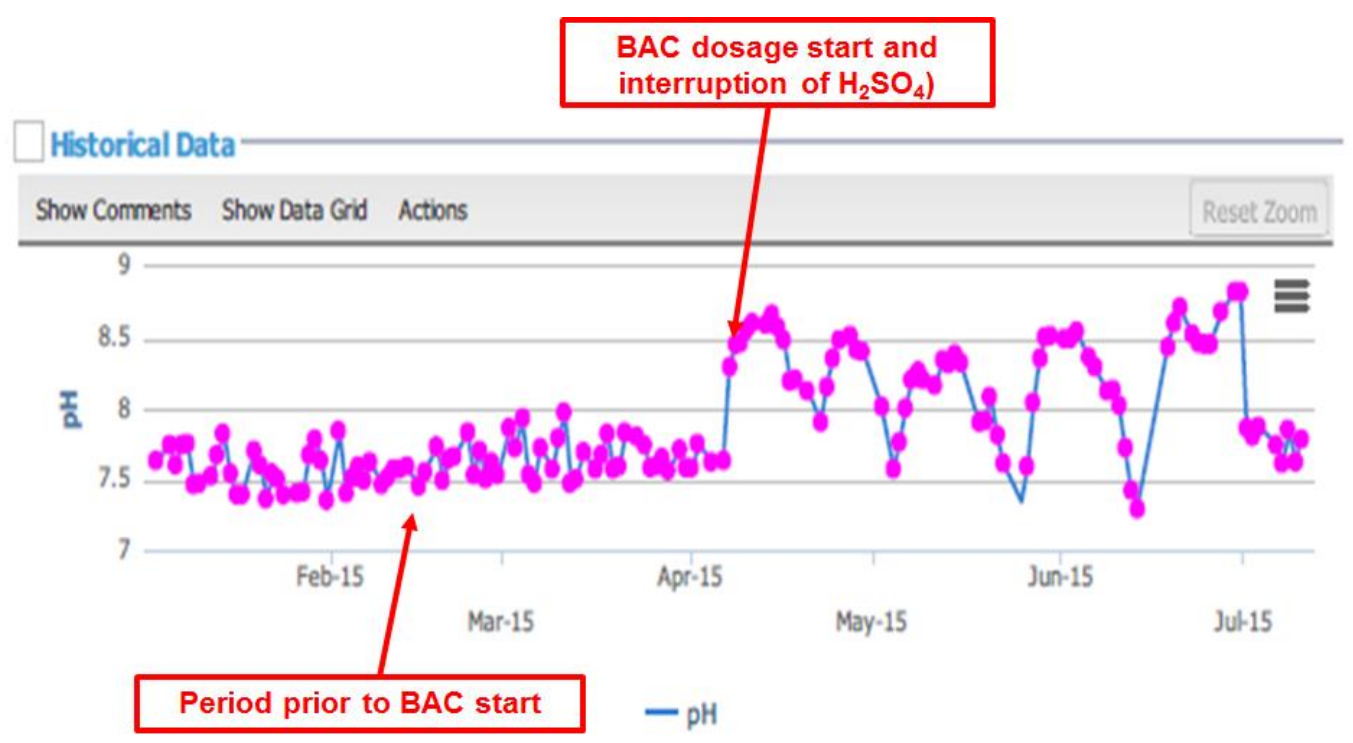

Figure $4-\mathrm{pH}$ profile before and after the BAC dosage start.

Since there was an immediate interruption of sulfuric acid consumption, a very large reduction was observed on the average sulfate residual in the recirculating water. That represented a $41 \%$ reduction in sulfate concentration in the recirculating water. 


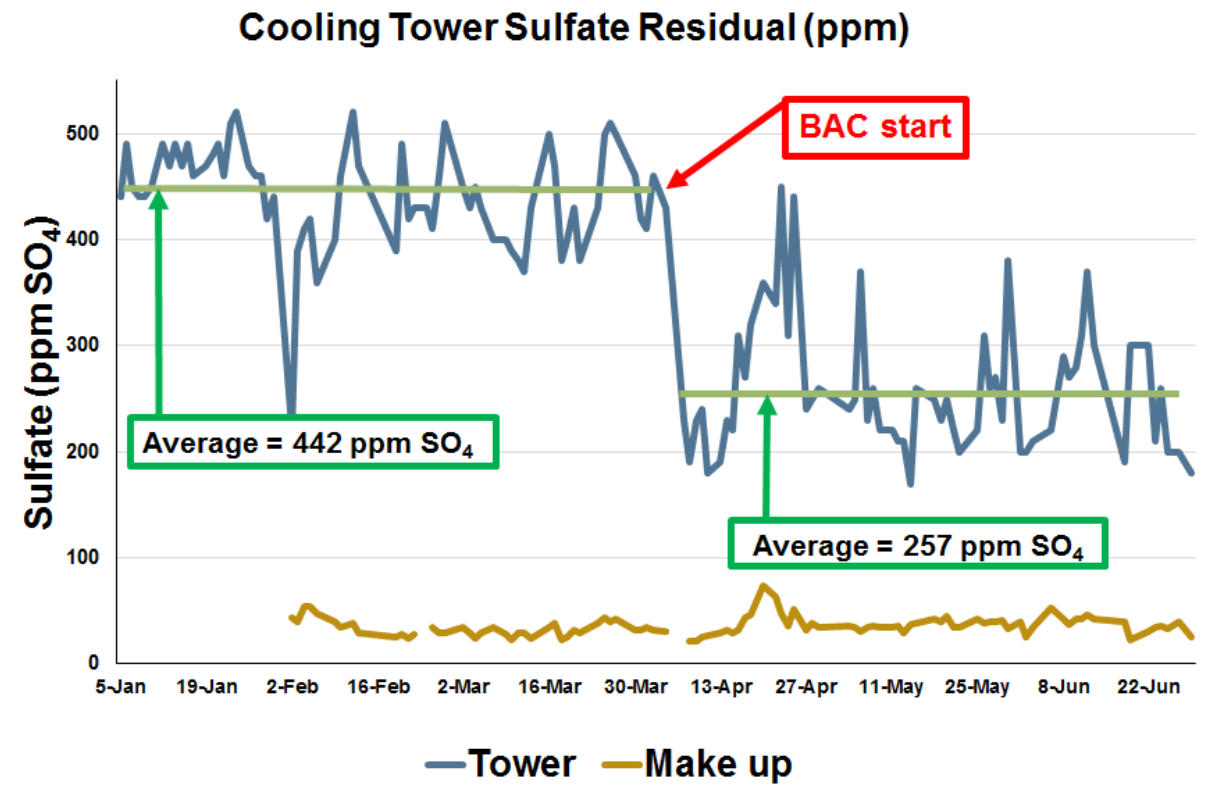

Figure 5 - Sulfate reduction in the recirculating water.

Once the sulfate residual was greatly reduced, the plant was comfortable in raising the concentration cycles for the cooling tower. This was not possible before since the plant was highly focused on keeping $\mathrm{Cl}+\mathrm{SO}_{4}$ below $600 \mathrm{ppm}$. With the change of the oxidizer, the plant went from an average of 4.5 cycles up to 6.5 cycles, representing a reduction of $18 \%$ of water being lost to the blowdown.

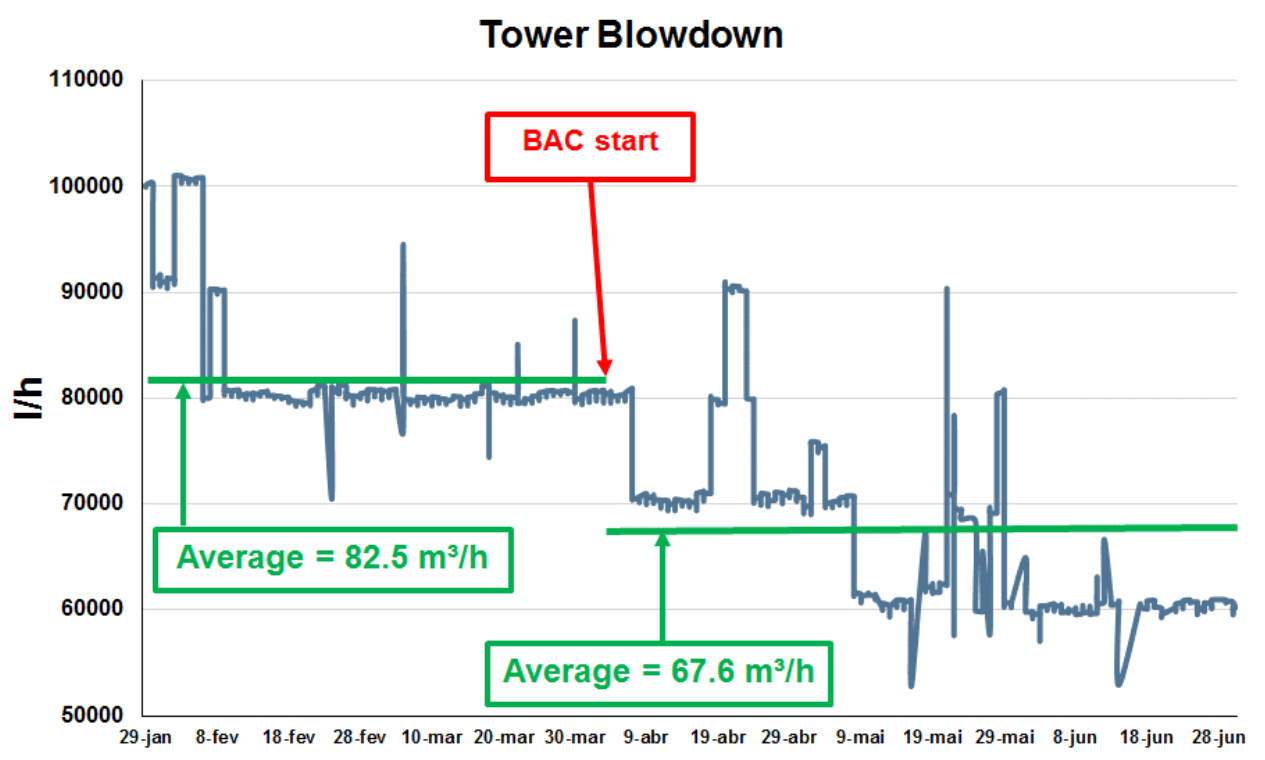

Figure 6 - Reduction on tower blowdown.

As described before, due to its mild oxidizing nature, the application of the chloramine resulted in a less corrosive environment. Once the chloramine dosage started, there was a reduction in average ORP as can be seen in Figure 7 . This resulted in a reduction in 316 stainless steel corrosion rates, as shown in Figure 8, measured with corrosion coupons according to NACE and ASTM standards. The corrosion rate before BAC usage was below/on the limit for this metallurgy. However, the BAC provided an improvement of $20 \%$ reduction on 316 SS corrosion rate. 


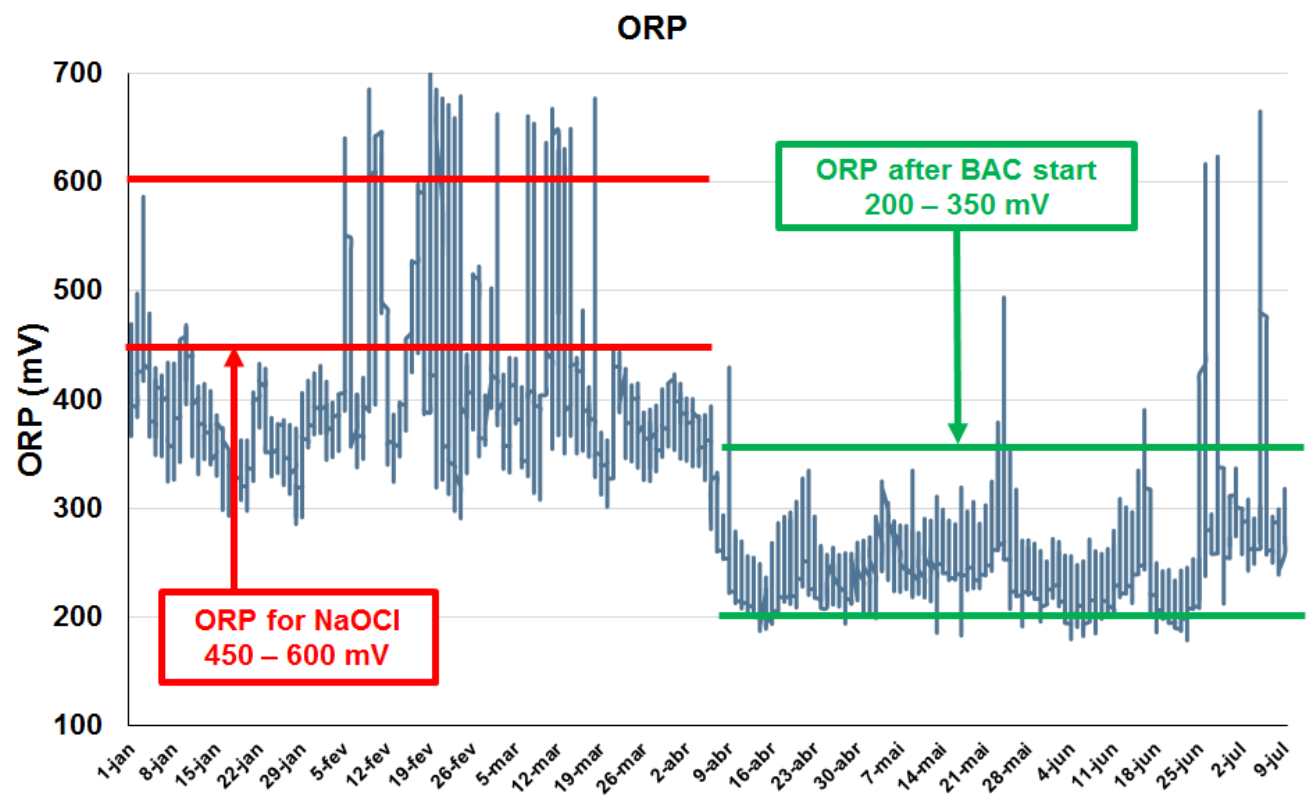

Figure 7 - ORP residuals before and during the BAC usage.

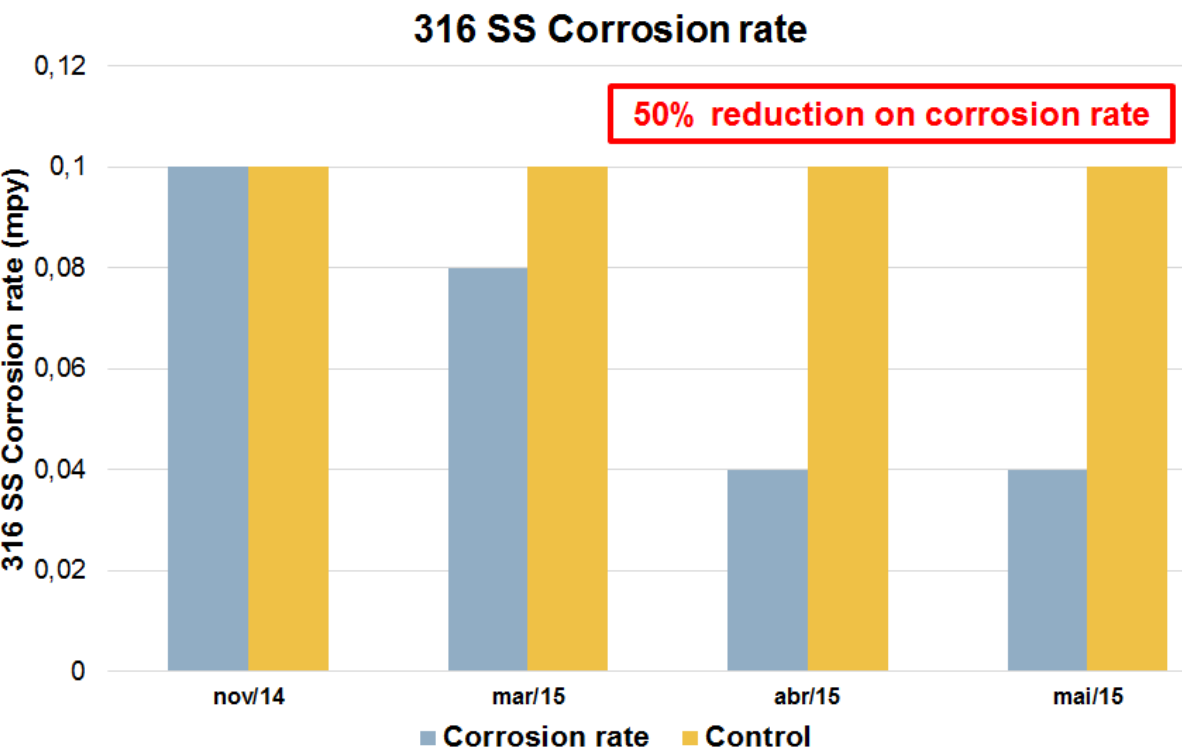

Figure 8 - Reduction on 316 stainless steel corrosion rate (measured by standard corrosion coupons).

The plant took its programmed shut down for maintenance and inspection in September 2015. This provided an opportunity to compare inspection findings on the surface condenser and cooling tower with the previous inspection findings from the turnaround in September 2014 (5 months before BAC start). The visual inspection showed an absolute improvement in biological control. In 2014, slime and biofilm was evident in the condenser and the cooling tower. In 2015 there was a complete absence of slime and biofilm as can be seen in Figures 9 and 10. In 2014 and in the previous years, it was very common to observe formation of biofilm almost in all areas. Not only was it possible to discern a much cleaner surface in the interior of the condenser, the 
cooling tower itself was also free of any kind of biofilm, sludge or suspended solids results. Figure 9 shows the surface condenser during the inspections in September 2014 and 2015. Figure 10 shows the cooling tower fill and basin during the inspection in September 2015.

It is also very important to notice that during the application of this new technology the bacteria counts were always below $10^{2} \mathrm{CFU} / \mathrm{ml}$.

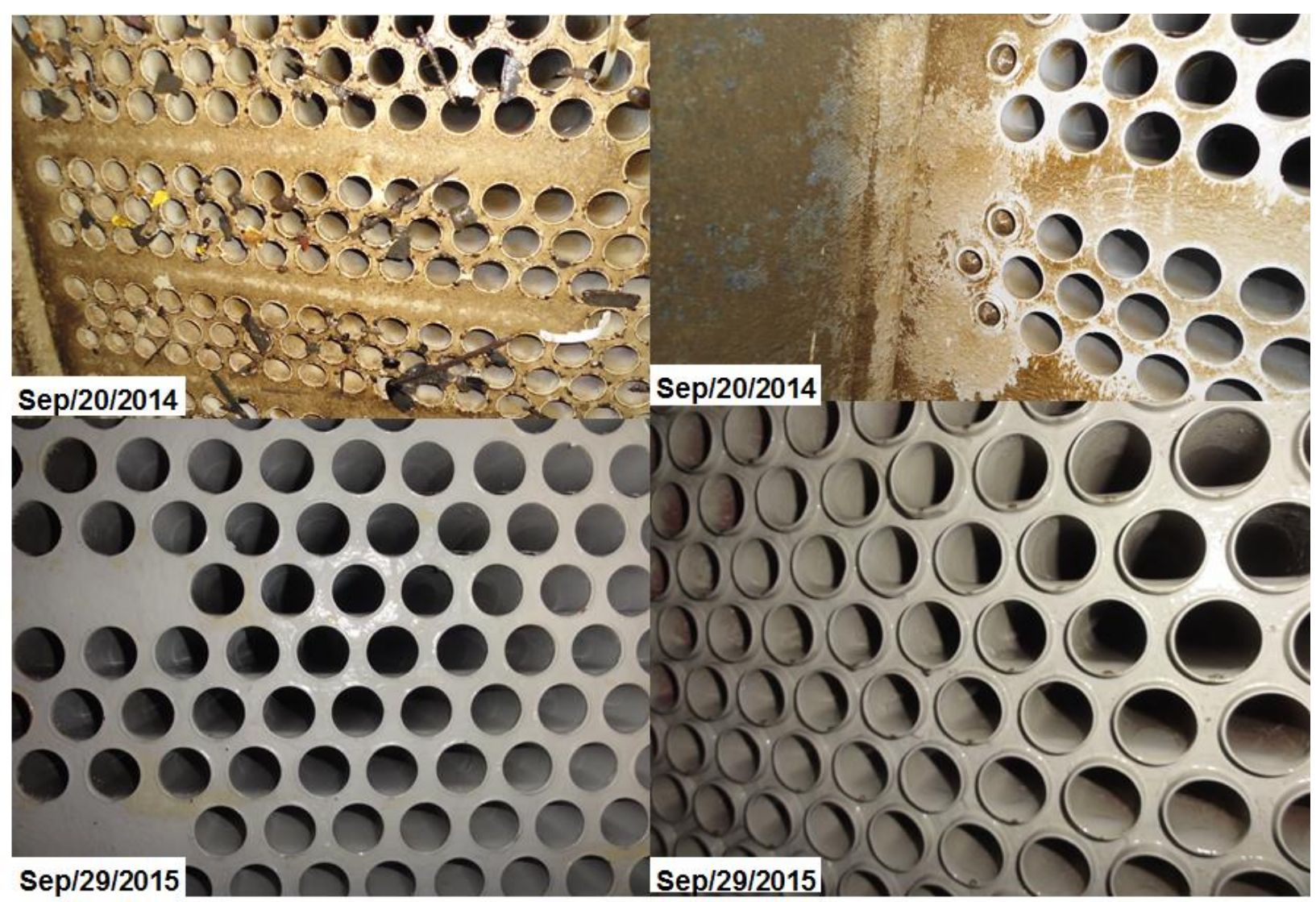

Figure 9 - Surface condenser inspected in September 2014 and September 2015. 

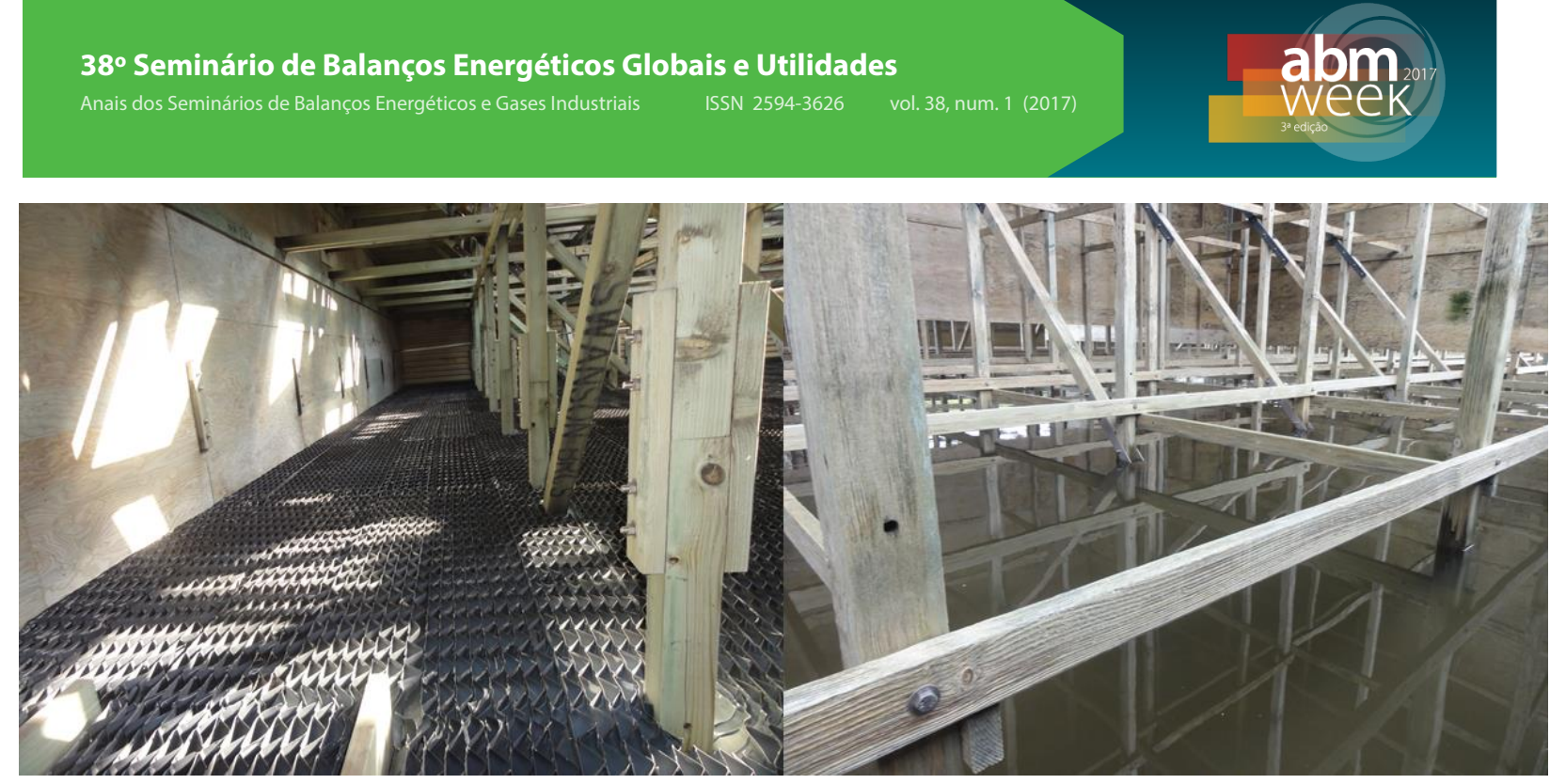

Figure 10 - Cooling tower inspected in September 2015.

\subsection{SAVINGS}

The observed data from the cooling tower showed many advantages on the application of the novel mild oxidizer technology compared to the previous period using sodium hypochlorite. Prior to BAC it was common practice for the plant to pressure wash the condenser and cooling tower during turnarounds. For 2015, the plant decided no cleaning or flushing in cooling tower fill nor the condenser was necessary.

In keeping with the objectives set by the plant prior to the biocide change, the direct savings in chemicals and water are tabulated below. However, it should be noted that there are other significant savings that are not captured here - improve condenser efficiency and elimination of cleaning costs.

\begin{tabular}{|c|c|c|c|}
\hline Item & Before & After & Savings \\
\hline $\mathrm{NaOCl}$ consumption (kg/month) & $\sim 40000$ & $\sim 4000$ & US $\$ 13,703 /$ month \\
\hline $\mathrm{H}_{2} \mathrm{SO}_{4}$ consumption ( $\mathrm{kg} /$ month) & $\sim 15000$ & 0 & US $\$ 4,263 /$ month \\
\hline Dispersant & $\sim 1400$ & $\sim 800$ & \multirow{3}{*}{ US\$ 4,959/month } \\
\hline Phosphonate & $\sim 450$ & $\sim 350$ & \\
\hline Ammonium bromide & 0 & $\sim 2000$ & \\
\hline Makeup water (m³/month) & $\sim 353,400$ & $\sim 324,850$ & US\$11,523/month \\
\hline & & $\mathbf{L}$ & $\begin{array}{l}\text { US } \$ 34,448 / \text { month } \\
\text { US } \$ 413,376 / \text { year }\end{array}$ \\
\hline
\end{tabular}

Table 4 - List of benefits with the application of BAC.

\section{CONCLUSIONS}

The application of the new bromide activated chloramine provided the established objectives defined in the project. The mains observations and conclusions include:

$\rightarrow$ Greater selectivity of the new biocide for microorganisms and little or no consumption by other oxidant demand. In this specific case, especially ammonia and organics. 
$\rightarrow$ Elimination of sulfuric acid usage. This allowed the system for a reduction of $41 \%$ in sulfate residual and the plant personnel felt more comfortable about past SCC failures.

$\rightarrow$ Reduction on hypochlorite consumption in about $90 \%$.

$\rightarrow$ Lower ORP levels. And 50\% reduction on 316 stainless steel corrosion rate.

$\rightarrow$ Overall cleanliness and virtually zero formation of biofilm. It was not necessary to perform any kind of flushing or cleaning on both the condenser and cooling tower.

$\rightarrow$ Increased cooling water concentration cycles from 4.5 to 6.5 .

\section{REFERÊNCIAS}

1 Baron, C. (2012). Biosperse XD3899 Microbiocide: A Novel Microbial Control Agent For Cooling Towers. Cooling Technology Institute, TP12-24.

2 Baron, C. and Hammond, S. (2015). Improve System Performance and Reduce System Corrosivity Using A Novel Biocide For Cooling Towers. Cooling Technology Institute, TP15-20.

3 Baron, C. (2012). Optimization of Cooling Tower Treatment Programs Using a Novel, Mild Oxidant for Microbiological Control. International Water Conference. IWC12-02.

4 Baron, C. (2012). Novel, Mild Oxidant Improves Cooling Water Treatment Performance Relative to Traditional Oxidizers. Cooling Technology Institute. TP12-24.

5 Beardwood, E. (2014). Introduction to the Use of Monohaloamine in Cooling Waters; Field Validation Results. Internal Report, Solenis LLC.

6 Beardwood, E. (2011). Treatment and Performance Management for Cooling Waters. NACE Corrosion 2011, Paper No. 11-388.

7 Frayne, Colin (1999). Cooling Water Treatment: Principles and Practice. McGraw-Hill.

8 Kiuru, J. (2011). Interactions of Chemical Variations and Biocide Performance at Paper Machines. Doctoral Dissertation, Aalto University, Aalto, Finland.

9 Peskin, A. V. and Winterbourn, C. C. (2006). Taurine chloramine is more selective than hypochlorous acid at targeting critical cysteines and inactivating creatine kinase and glyceraldehyde-3-phosphate dehydrogenase. Free Radical Biology and Medicine, Volume 40 Issue 1, Pages 45-53. 